\title{
Evaluation of retina and nerve fiber layers with swept source optic coherence tomography in inflammatory bowel diseases
}

\section{Inflamatuar barsak hastalıklarında swept source optik koherens tomografi ile retina ve sinir lifi tabakalarının değerlendirilmesi}

\section{Cenk Zeki FiKRET ${ }^{1}$ (ID), Nil İrem UÇGUN² (ID), Filiz YILDIRIM³ ${ }^{3}$ (ID), Enver AVCl$^{4}$ (ID), Mevluit $\mathrm{HAMAMCI}^{5}$ (ID)}

\section{ABSTRACT}

Objective: To evaluate ocular involvement in inflammatory bowel diseases (IBD) with swept source optical coherence tomography and to determine whether the detected parameters can be disease activation criteria.

Methods: 57 eyes of 30 patients with Ulcerative colitis (UC), 32 eyes of 16 patients with Crohn's Disease (CD) and 78 eyes of 53 healthy individuals were included in our study. Retinal Nerve Fiber thickness (RNFL), Ganglion cell layer $(\mathrm{GCL}++)$, Central macular thickness (CMT) and Choroidal thickness (CT) measurements were done by swept source optical coherence tomography (SS OCT). Crohn's Disease Activity Index (CDAl) was also detected in patients with $\mathrm{CD}$. Blood $\mathrm{C}$ reactive protein (CRP), neutrophil, hemoglobin (HGB), and sedimentation values were measured in patients with $U C$ and $C D$.

Results: The mean age was $38.6 \pm 8.8$ in $C D$, $42.9 \pm 12.2$ in $U C$, and $53.7 \pm 12.6$ years in the control group. In CD, RNFL was significantly thicker and GCL ++ significantly thiner when compared with the control group. CMT values and CDAl values show a statistically significant negative correlation. There was negative

\section{ÖZET}

Amaç: Bu çalıșma, inflamatuar barsak hastalıkları (iBH)'ındaki oküler tutulumu taranmıș kaynaklı (swept source) optik koherens tomografi ile değerlendirmek ve tespit edilen parametrelerin hastalık aktivasyon kriteri olup olmadığını belirlemek amacıyla yapıldı.

Yöntem: Çalıșmamıza ülseratif koliti olan 30 hastanın 57 gözü, Crohn hastalığı olan 16 hastanın 32 gözü ve 53 sağlıklı bireyin 78 gözü dahil edildi. Retina Sinir Lifi kalınlığı (RNFL), Ganglion hücre tabakası (GCL++), Santral maküla kalınlığı (CMT) ve Koroid kalınlığı (CT) ölçümleri swept source optik koherens tomografi (SS OCT) ile yapıldı. Crohn hastalığı olan hastalarda da Crohn hastalığı aktivite indeksi (CDAl) tespit edildi. Crohn hastalığı ve ülseratif koliti olan hastaların kanında C reaktif protein (CRP), nötrofil, hemoglobin (HGB) ve sedimantasyon düzeyleri ölçüldü.

Bulgular: Çalıșma grubunun yaș ortalaması Crohn hastalığında $38.6 \pm 8.8$, ülseratif kolitte $42.9 \pm 12.2$ ve kontrol grubunda $53.7 \pm 12.6$ yll idi. Crohn hastalığında RNFL, kontrol grubuna kıyasla anlamlı derecede daha kalın ve GCL++ anlamlı olarak daha ince idi. CMT değerleri ve CDAI değerleri, istatistiksel olarak anlamlı negatif bir korelasyon

${ }^{1}$ Ankara City Hospital, Department of Ophthalmology, Ankara

${ }^{2}$ University of Health Science, Ankara City Hospital, Department of Ophthalmology, Ankara

${ }^{3}$ Polatlı Duatepe Government Hospital, Clinic of Internal Medicine, Polatl, Ankara

${ }^{4}$ Medicana Konya Hospital, Department of Internal Medicine and Hepato-Gastroenterology, Konya

${ }^{5}$ Gulhane Education and Training Hospital, Department of Internal Medicine and Hepato-Gastroenterology, Ankara

İletişim / Corresponding Author : Filiz YILDIRIM

Karapınar, Eskişehir Yolu üzeri Abdülaziz Cad. No: 2, 06900 Polath / Ankara - Türkiye

E-posta / E-mail :drfyildirim@yahoo.com

Geliş Tarihi / Received : 28.05.2021 Kabul Tarihi / Accepted : 05.10.2021

DOI ID : 10.5505/TurkHijyen.2021.92342

Fikret CZ, Uçgun Ni, Yıldırım F, Avcı E, Hamamcı M. Evaluation of retina and nerve fiber layers with swept source optic coherence tomography in inflammatory bowel diseases. Turk Hij Den Biyol Derg, 2021; 78(4): 493 - 498 
correlation between CT and CDAl levels. UC patients were not different in RNFL compared to the control group, but GCL ++ was thin. Superior RNFL was thicker in patients with UC. There was no difference in CMT and CT measurements in all groups. The levels of HGB in the serum were significantly higher in the UC group than in the CD group. A significant difference was not detected when the levels of serum CRP, neutrophil, and sedimentation of the UC group compared with the CD group.

Conclusion: RNFL and $\mathrm{GCL}++$ thickness measurements may be determinative for ocular involvement in patients with inflammatory bowel disease.

Key Words: Inflammatory bowel diseases, retinal nerve fiber layer, ganglion cell layer, optic coherens tomography gösterdi. CT ve CDAl seviyeleri arasında negatif korelasyon vardı. Ülseratif kolit hastaları RNFL değerleri kontrol grubuna göre farklı değildi, ancak GCL++ daha ince bulundu. Ülseratif kolitli hastalarda superior RNFL'nin daha kalın olduğu saptandı. Tüm gruplarda CMT ve CT ölçümlerinde fark yoktu. Ülseratif kolit grubu Crohn hastalığı grubu ile karșılaștıııldığında serum HGB düzeylerinin anlamlı olarak arttığı görüldü. Ülseratif kolit grubu Crohn hastalığı grubu ile karșlaștırıldığında serum CRP, nötrofil ve sedimantasyon düzeylerinde bir fark saptanmadl.

Sonuç: RNFL ve GCL++ kalınlık ölçümleri, inflamatuar barsak hastalığı olan hastalarda oküler tutulum için belirleyici olabilir.

Anahtar Kelimeler: İnflamatuar bağırsak hastalıkları, retina sinir lifi tabakası, ganglion hücre tabakası, optik koherens tomografi

\section{INTRODUCTION}

Inflammatory bowel disease (IBD), including Crohn's Disease (CD) and ulcerative colitis (UC), is considered a systemic disease as it coexists with extraintestinal symptoms. Beside joints and skin, the eye is the third major tissue type prone to immune-mediated extra intestinal manifestations (1). Extraintestinal symptoms are the first signs in $10-20 \%$ of cases in IBD (2).

Nearly, $2 \%$ to $5 \%$ of patients with IBD experience ocular manifestations. Ocular symptoms have been reported to be more common in patients with $C D$ (3.5-6.3\%) than in patients with UC (1.6-4.6\%) (3). Episcleritis, scleritis and uveitis are common ocular findings in inflammatory bowel disease (2). Studies have reported that posterior segment involvement in IBD is less than $1 \%$. These patients had optic neuritis in $4 \%$ and cystoid macular edema in $20 \%$. Other rare complications of the posterior segment are retinal vasculitis and serous retinal detachment due to posterior uveitis or posterior skleritis (4).
The pathophysiology of IBD is uncertain, but genetics, environment, psychological, microbiological and immunological factors have been reported to be influential. The pathophysiology responsible for extra intestinal involvement is the interaction of allergic and immune reactions and the accumulation of immune complexes in extra-intestinal areas $(5,6)$.

Swept source optic coherens tomography (SS-OCT) is more useful than spectral domain optical coherence tomography (OCT) in choroid imaging with deeper penetration effect. Whether the choroid is thin or thick it gives information about retinal diseases (7).

We measured central macular thickness (CMT), choroidal thickness (CT), retinal nerve fibre layer (RNFL), ganglion cell layer ++ (GCL++ = RNFL+ GCL+ Inner plexiform layer (IPL) ) thickness, and blood parameters in patients with IBD, considering that it could also be affected by intraocular inflammation. We aimed to detect ocular involvement in IBD patients with SS-OCT. 


\section{MATERIAL and METHOD}

SBÜ Ankara Numune City Hospital Ethic Committee and Human Ethical Committee approval (Date: 10.01.2019 and Number: E-18-2439) was obtained for this study, the tenets of the Declaration of Helsinki were observed. Written informed consent was obtained from all patients. This study is a crosssectional prospective observational study.

57 eyes of 30 patients with UC, 32 eyes of 16 patients with CD and 78 eyes of 53 healthy individuals were included in our study.

RNFL, Inferior RNFL (IRNFL), Superior RNFL (SRNFL), GCL ++ (Ganglion cell layer+ RNFL+Inner plexiform layer), CMT and subfoveal CT measurements were done by swept source optical coherence tomography (DRI Triton swept source optical coherence tomography; Topcon, Tokyo, Japan). Blood $C$ reactive protein (CRP), neutrophil, hemoglobin (HGB), and sedimentation values were measured in patients with UC and CD.

Crohn's Disease Activity Index (CDAI) was also detected in patients with CD (8). Patients with CDAl scores of less than 150 were considered in remission and included in our study. CD patients in the asymptomatic remission period were included in the study.

Patients with IBD were included in the study after they were found to be in remission by monitoring their blood CRP, neutrophil, HGB and sedimentation values.
Patients with spherical equivalent values greater than \pm 4.0 diopters, glaucoma, optic neuropathy, uveitis, retinopathy, ocular trauma and previous intraocular surgery were excluded. Patients with neurological and systemic vascular disease were also excluded from the study.

Ophthalmic examinations of all patients were performed.

Independent sample T-Test was used for statistical analysis of the data. Pearson's chi-square test and One-way ANOVA test were also used for analysis. Pearson correlation test was used to evaluate the relationship between the data. It was considered statistically significant when $p$ value was less than 0.05 .

\section{RESULTS}

Demographic data of the groups are shown in Table 1. The mean age was $38.6 \pm 8.8$ in $C D, 42.9 \pm 12.2$ in UC, and $53.7 \pm 12.6$ years in the control group. The average age of the individuals included in the control group was found to be statistically significantly higher than the other groups $(p<0.001)$. Male gender in UC is significantly higher than other groups $(p<0.001)$.

In $C D$, RNFL $(p=0.02)$, IRNFL $(p=0.02)$ were significantly thick and GCL ++ $(p<0.001)$ was significantly thin when compared with the control group. A moderate positive correlation was found between RNFL values and sedimentation values in $C D$ patients $(r=0.50, p=0.003)$. IRNFL values had $a$

Table 1. Demographic data of the groups

\begin{tabular}{|c|c|c|c|c|c|c|c|}
\hline & \multicolumn{2}{|c|}{ Crohn's disease $(n=16)$} & \multicolumn{2}{|c|}{ Ulcerative colitis $(n=30)$} & \multicolumn{2}{|c|}{ Control $(n=53)$} & \multirow[b]{2}{*}{$\mathrm{p}$} \\
\hline & $\mathrm{n}$ & $\%$ & $\mathrm{n}$ & $\%$ & $\mathrm{n}$ & $\%$ & \\
\hline Female & 13 & 81.3 & 11 & 36.7 & 25 & 64,1 & \multirow{2}{*}{$<0,001^{*}$} \\
\hline Male & 3 & 18.8 & 19 & 63.3 & 28 & 35.9 & \\
\hline Mean Age (Year) & \multicolumn{2}{|c|}{$38.6 \pm 8.8$} & \multicolumn{2}{|c|}{$42.9 \pm 12.2$} & \multicolumn{2}{|c|}{$53.7 \pm 12.6$} & $<0,001^{*}$ \\
\hline
\end{tabular}


high positive correlation with sedimentation value $(r=0.77, p<0.001)$. It also shows moderate correlation with CRP value $(r=0.53, p=0.002)$. There was a negative correlation between CMT and CDAI values $(r=-0.61, p=0.01)$. Moderately negative correlation was found between CMT and sedimentation ( $r=-$ 0.57, $\mathrm{p}=0.001)$, CRP $(\mathrm{r}=-0.52, \mathrm{p}=0.002)$ values. There was statistifically significant negative correlation between CT and CDAl levels ( $r=-0.64, p=0.008)$.

UC patients were not particularly dissimilar in RNFL compared to the control group.

The SRNFL value of UC patients included in the study was higher than the control group $(p<0.001)$. IRNFL and GCL++ values of these patients were lower $(p<0.05)$. There was a weak negative correlation between SNRFL and neutrophil values of UC patients $(r=-0.27, p=0.04)$.

When UC and Crohn's patients were compared with the control group, there was no difference in CMT and CT measurements ( $p>0.005)$. The parameters determined in the OCT are reported in Table 2.

The average CDAl of Crohn's patients is 79.0 \pm 50.26 . Crohn's patients in the asymptomatic remission period were included in the study.

The levels of HGB in the serum were remarkably higher in the UC group than in the CD group. $A$ significant difference was not detected when the levels of serum CRP, neutrophil, and sedimentation of the UC group compared with the CD group. Blood tests of individuals with IBD are shown in Table 3.

Table 2. The parameters determined in the OCT

\begin{tabular}{|l|c|c|c|c|}
\hline & Crohn's disease & Ulcerative colitis & Control group & $p$ \\
\hline RNFL & $114.72 \pm 10.65$ & $111.37 \pm 8.61$ & $109.22 \pm 11.15$ & $0.02^{*}$ \\
\hline SNRFL & $137.25 \pm 18.79$ & $143.37 \pm 16.79$ & $132.47 \pm 17.92$ & $0.001^{* *}$ \\
\hline IRNFL & $152.28 \pm 19.53$ & $133.21 \pm 13.75$ & $142.49 \pm 19.03$ & $0.02^{* * *}$ \\
\hline CMT & $236.84 \pm 20.79$ & $238.30 \pm 20.19$ & $246.24 \pm 30.87$ & $p>01^{* * * *}$ \\
\hline CT & $328.59 \pm 54.95$ & $329.91 \pm 72.29$ & $310.67 \pm 60.45$ & $p>0.05$ \\
\hline GCL++ & $38.19 \pm 19.54$ & $34.32 \pm 13.51$ & $62.57 \pm 18.64$ & $0.001^{* * * * *}$ \\
\hline
\end{tabular}

* In Crohn's Disease, RNFL was significantly thicker when compared with the control group.

** In Ulcerative colitis patients, SRNFL was significantly thicker when compared with the control group.

*** IRNFL was significantly thicker in Crohn's Disease when compared the patients with Ulserative colitis and control group.

**** IRNFL was significantly thiner in the patients with ulcerative colitis when compared the control group.

***** GCL++ was significantly thiner in the patients with ulcerative colitis and Crohn's Disease when compared the control group.

Table 3. Blood tests of individuals with IBD

\begin{tabular}{|l|c|c|c|}
\hline & Crohn's disease & Ulcerative colitis & $p$ \\
\hline Sedimentation & $22.31 \pm 19.20$ & $22.75 \pm 22.88$ & 0.180 \\
\hline CRP & $6.00 \pm 10.98$ & $7.45 \pm 10.45$ & 0.479 \\
\hline Neutrophil & $5.13 \pm 1.80$ & $5.32 \pm 3.13$ & 0.268 \\
\hline HGB & $12.76 \pm 1.27$ & $13.14 \pm 2.21$ & $<0,001^{*}$ \\
\hline
\end{tabular}

*HGB levels were significantly higher in the patients with ulcerative colitis when compared the Crohn's Disease group. 


\section{DISCUSSION and CONCLUSION}

In this study; GCL++ was observably thiner in the patients with UC and CD when compared the control group. We detected RNFL and IRNFL were relevantly thicker in $C D$, when compared with the control group. RNFL measurement was higher in patients with UC, but it was not significant. We evaluated that SRNFL values of UC patients were higher than the control group. In addition, patients with UC had lower IRNFL values.

Initial degenerative changes in the retina and optic nerve are asymptomatic and cannot be detected by diagnostic tests such as visual field. Measurement of GCL and RNFL thicknesses at early stages with OCT is important in reaching early diagnosis. According to information from the glaucoma continuum table, the first affected is GCL, then the RNFL is affected (9).

Optic neuropathy and optic neuritis are also seen in IBD (4). In optic neuropathy, edema and edemarelated thickening are not observed in GCL. After neuronal cell death, thinning of GCL due to atrophy is detected. In the onset of optic neuritis, even if the optic nerve is clinically normal, thickening of RNFL is observed. Thinning in GCL is detected in 1 month. For this reason, the GCL measurement gives more information than the RNFL measurement. RNFL measurements in the first 2 months are thick due to edema and do not show axonal loss. RNFL thickness typically stabilizes by 6 months (10).

RNFL thinning was also detected in OCT measurements performed in neurodegenerative diseases such as Alzeimer's and Parkinson Disease. In Multiple Sclerosis (MS), nerve damage occurs along with inflammatory and neurodegenerative mechanisms. Thinning in RNFL and GCL is also reported in MS Disease (10).

Optic nerve damage in IBD can be due to ischemia and inflammation. Neuroretinitis, papillitis, optic (demyelinating) neuritis or ischemic optic neuropathy can be seen in IBD. In addition, optic nerve damage due to intracranial hypertension may occur in IBD (11).
Neurological manifestations are more common than predicted in IBD. Thrombotic complications of the central nervous system are common in patients with IBD. MS Disease also can be detected in patients with IBD (12).

Therefore, it is useful to follow patients with IBD at regular intervals with OCT. Complications affecting the ocular and central nervous system can be detected at an early stage by monitoring $\mathrm{GCL}$ and RNFL in IBD.

Onal et al. found that there was no significant change in $C T$ in IBD, but there was a significant correlation between CDAI and CT (13). He and colleagues found that the choroidal thickness increased in IBD, and they thought it was a determining marker for IBD (14). In our study, we did not find a remarkable difference in CT thickness in patients with IBD. Another important point is that although we did not find any difference in choroid thickness in IBD, but there was a correlation between CDAl ratio and $C T$ in patients with $C D$.

In IBD patients, blood sedimentation, CRP, neutrophil, HGB values were examined to evaluate disease activity and severity. Patients with IBD were included in the study after they were found to be in remission by monitoring their blood CRP, neutrophil, HGB and sedimentation values. Correlations between OCT parameters and blood values mearured in IBD patients indicate ocular involvement.

One of the common ocular pathologies in IBD is uveitis $(0.05 \%-3.5 \%)$. Macular edema in patients with uveitis causes decreased visual acuity. OCT is the most effective noninvasive method used in the diagnosis and follow-up of macular edema (15-17). In our study, there was no difference between CMT and the control group for CMT. This may be due to the absence of active uveitis in our patients with IBD.

In conclusion: In our study, we found that RNFL and $\mathrm{GCL}++$ were affected in IBD patients with the swept source OCT. We think that RNFL and GCL ++ measurements are useful in early detection of ocular and central nervous system involvement in IBD. The 
high mean age of the control group and the excess of male patients in UC patients caused our study to be limited. Ocular involvement should be kept in mind in IBD and patients should undergo ophthalmic examination at regular intervals. Further research is needed to declare that OCT findings are useful in diagnosing and follow-up of IBD.

\section{ETHICS COMITTEE APPROVAL}

* The study was approved by SBÜ Ankara Numune City Hospital Ethic Committee and Human Ethical Committee (Date: 10.01.2019 and Number: E-18-2439).

\section{CONFLICT OF INTEREST}

The authors declare no conflict of interest.

\section{REFERENCES}

1. Vavricka SR, Schoepfer A, Scharl M, Lakatos PL, Navarini A, Rogler G. Extraintestinal Manifestations of Inflammatory Bowel Disease. Inflamm Bowel Dis, 2015; 21: 1982-92.

2. Greenstein AJ, Janowitz HD, Sachar DB. The extraintestinal complications of Crohn's disease and ulcerative colitis. Medicine, 1976; 55: 401-12.

3. Velaso FT, Carvalho J, Magro F. Immune-related Systemic Manifestations of Inflammatory Bowel Disease. A Prospective Study of 792 Patients. J Clin Gastroenterol, 1996; 23(1): 29-34.

4. Felekis T, Katsanos K, Kitsanou M, Trakos N, Theopisos V, Christodoulou D, Asproudis I, Tsianos EV. Spectrum and Frequency of Ophthalmologic Manifestations in Patients with Inflammatory Bowel Disease: A Prospective Single-Center Study. Inflamm Bowel Dis, 2009; 15: 29-34.

5. Ananthakrishnan AN. Epidemiology and risk factors for IBD. Nat Rev Gastroenterol Hepatol, 2015; 12: 205-17.

6. Yilmaz S, Aydemir E, Madem A, Unsal B. The prevalence of ocular involvement in patients with inflammatory bowel disease. Int J Colo- rectal Dis, 2007; 22: 1027-30.

7. Zhou H, Chu Z, Zhang Q, Dai Y, Gregori G, Rosenfeld PJ, Wang RK. Attenuation Correction Assisted Automatic Segmentation for Assessing Choroidal Thickness and Vasculature With Swept-Source OCT. Biomed Opt Express, 2018; 9: 6067-80.

8. Cheifetz AS. Management of Active Crohn Disease. JAMA, 2013; 309: 2150-58.

9. Weinreb RN, Friedman DS, Fechtner RD, Cioffi GA, Coleman AL, Girkin CB, Liebmann JM, Singh K, Wilson MR, Wilson R, Kanal BK. Risk Assessment in the Management of Patients With Ocular Hypertension. Am J Ophthalmol, 2004; 138: 458-67.
10. Maldonado RS, Mettu P, El-Dairi M, Bahatti MT. The application of optical coherence tomography in neurologic diseases. Neurol Clin Pract, 2015; 5: 460-9.

11. Katsanos A, Asproudis I, Katsanos KH, Dastiridou Al, Aspiotis M, Tsianos EV. Orbital and optic nerve complications of inflammatory bowel disease. Journal of Crohn's and Colitis, 2013; 7: 683-93.

12. Zois $\mathrm{CD}$, Katsanos $\mathrm{KH}$, Kosmidou M, Tsianos EV. Neurologic manifestations in inflammatory bowel diseases: Current knowledge and novel insights. Journal of Crohn's and Colitis, 2010; 4:115-24.

13. Onal IK, Yüksel E, Bayrakceken K, Demir MM, Karaca EE, Ibis M, Alizadeh N, Sargın ZG, Hondur AM, Arhan M. Measurement and clinical implications of choroidal thickness in patients with inflammatory bowel disease. Arq Bras Oftalmol, 2015; 78: 278-82.

14. He k, Zhang P, Li X. Relationship between disease activity and choroidal thickness in patients with inflammatory bowel disease. Recent Advances in Ophthalmology, 2017; 37: 469-72.

15. Troncoso LL, Biancardi AL, De Moraes Jr HV, Zaltman C. Ophthalmic manifestations in patients with inflammatory bowel disease: a review. World J Gastroenterol, 2017; 23: 5836-48.

16. Massa H, Pipis SY, Adewoyin T, Vergados A, Patra S, Panos GD. Macular edema associated with non-infectious uveitis: pathophysiology, etiology, prevalence, impact and management challenges. Clinical Ophthalmology, 2019; 13: 1761-77.

17. Fardeau C, Champion E, Massamba N, LeHoang P. Uveitic macular edema. Eye, 2016; 30: 1277-92. 